\title{
SXM analysis of nanoscale electron transfer processes at the cell-mineral interface in Co-bearing $\mathrm{Fe} / \mathrm{Mn}$ minerals
}

D.M. BUCHANAN ${ }^{1 *}$, J.R. LLOYD ${ }^{1}$, B. KAULICH ${ }^{2}$, L. NEWSOME ${ }^{1}$, D.S. MULROY ${ }^{1}$, G. VAN DER LAAN ${ }^{2}$, A. N'DIAYE ${ }^{3} \&$ V.S. COKER ${ }^{1}$

${ }^{1}$ Department of Earth \& Environmental Sciences, University of Manchester, Oxford Road, M13 9PL, UK

("dawn.buchanan@postgrad.manchester.ac.uk)

${ }^{2}$ Diamond Light Source, Harwell Science and Innovation Campus, Fermi Ave, Didcot OX11 0DE, UK

${ }^{3}$ The Advanced Light Source, 6 Cyclotron Rd, Berkeley, CA 94720, USA

Cobalt is a critical commodity primarily due to usage in rechargeable batteries. This demand, combined with supply risk, has driven a need to find and exploit other geological sources. Cobalt, as $\mathrm{Co}(\mathrm{III})$, can be found incorporated into the crystal lattice of minerals such as ferrihydrite $\left[\mathrm{Fe}^{3+}{ }_{10} \mathrm{O}_{14}(\mathrm{OH})_{2}\right]$ and asbolane $\left[(\mathrm{Ni}, \mathrm{Co})_{\mathrm{x}} \mathrm{Mn}^{4+}(\mathrm{OOH})_{4} \bullet \mathrm{nH}_{2} \mathrm{O}\right]$. These minerals are potential new Co sources in lateritic ores and deep sea nodules. Dissimilatory metal-reducing bacteria, ubiquitous in the subsurface, can use $\mathrm{Fe} / \mathrm{Mn}$-oxides as terminal electron acceptors for microbial respiration, coupled to the oxidation of organic matter. However, electron transfer processes occurring at the cell-mineral interface in these systems remain ill-defined. Understanding the complex biogeochemical interactions of bacteria with $\mathrm{Co}-\mathrm{Fe} / \mathrm{Mn}-$ oxides is critical for the exploitation of these future resources. Synchrotron-based scanning X-ray microscopy (SXM) was used to investigate changes in the speciation of metals and organic compounds at the nanoscale through X-ray absorption spectroscopy (XAS) coupled with geochemical data and transmission electron microscopy (TEM).

Enzymatic reduction of Co-rich $\mathrm{Fe} / \mathrm{Mn}$-minerals by Geobacter sulfurreducens was investigated and release of soluble cobalt was observed during reduction together with changes in mineral morphology. From bulk $\mathrm{Mn} L_{2,3}$-edge XAS data, the ratio of $\mathrm{Mn}(\mathrm{IV}): \mathrm{Mn}(\mathrm{III}): \mathrm{Mn}(\mathrm{II})$ changed from $58: 17: 25$ to $30: 28: 42$, indicating biogenic reduction of asbolane. However, from SXM data, collected at the nanoscale, areas associated with biomass experience a higher initial rate of reduction compared to areas not associated with biomass; although, all areas ultimately show the same extent of reduction. These results demonstrate the ability of subsurface reductive processes to release the critical metal Co from mixed mineral phases associated with ore minerals and the necessity for considering the spatial variability of subsurface reductive processes. 